チャ冬芽の芽長と幼葉数の推移

静岡県茶業試験場*

中野敬之

静岡県立農林短期大学

大石 准**

(平成 5 年 3 月 22 日受理)

\title{
Changes in Length and Number of Leaf Primordia of Winter Bud in Tea
}

\author{
Takayuki NAKANO \\ Shizuoka Tea Experiment Station \\ Jun OoIsHI \\ Shizuoka Agriculture \& Forestry Junior College
}

\begin{abstract}
Growth of winter bud in tea plant was traced during the period from autumn to next spring. Bud length and number of leaf primordia in a bud were examined on six cultivars.

In all cultivars, both of the two parameters began to increase just after autumn skiffing, and ceased to grow at the beginning of December. After a dormant phase, a new increment of bud length was observed in some cultivars at the end of February. Re-increase in number of leaf primordia was detected only on relatively late-maturing cultivars, 'Yabukita', 'Kanayamidori' and 'Okuhikari'. Growth of winter bud in early spring was less as compared to that in autumn.
\end{abstract}

\section{1 緒訔}

栽培上に和ける茶芽の生育をみると，「摘 採・整枝 $\rightarrow$ 幼葉の分化と芽の肥大 $\rightarrow$ 萌芽 $\rightarrow$ 新 葉の展開 $\rightarrow$ 出開」の過程が年数回繰り返され るが，概ね摘採の順序から一，二，三番茶と なっている。しかし，各々の期間は異なり， 途中に冬季の休眠を経過する秋整枝から一番 茶摘採までの期間が最も長く，その中では萌 芽期以前が注とんどを占めている。作況をは しめとした一番茶芽の生育調查は萌芽期後が 慣例となって扣り，萌芽期前の生育を調査し た研究は少ない。それは，この間に大きな形 態的変化がみられないことに起因している。 そのため, 休眠, 耐谏性, 光合成, 内生物質 などの生理生態学の分野から生育特性の解明 が試みられている。
しかしこの間の形態的な变化は皆無では ない。例壳ば, 中山ら2)は春先に拈ける幼葉 の肥大や増加を報告している。芽の大きさや 幼葉数は，一番茶新芽の長さや展開葉数など の収量, 品質に大きな影響を及活す要素に関 連性が高い形質ある。また，萌芽期直前の芽 の肥大や色彩変化はほ場で容易に観察できる 形質で，栽培者はこれらを目安に生育の早堍 を推定することができる。萌芽期以前の茶芽 の生育状態を明らかにすることは，単に萌芽 期前の生育診断を可能にするだけでなく，こ れまで未知の部分が多からた一番茶の収量成 立過程の解明に貢献すると考克られる。

筆者らは，これまで不明であった春先以前 に拈ける冬芽の形態变化について調查した。 さらに，秋整枝から翌年一番茶萌芽期までの 期間で，早晚性の異なる品種間における形態

* $\overline{\mathbf{T} 439}$ 静岡県小笠郡菊川町倉沢1706-11

**现侏カワサキ技研 
变化の違いについて検討したので報告する。

\section{2 材料及び方法}

“お打いわせ，さやまかおり，やまかい， やぶきた，かなやみどり，拈くひかり’の6 品種を供試した。以上の品種は, 当場内で䄪 $36 \mathrm{a}$ の南北らねの茶園に同面積ずつ配置され ている。全て 1982 年定植で三番茶不摘採園 である。

1989 年 10 月 4 日に二番茶摘採面から $4 \sim 5$ cmの高さで一斉に秋整枝を行った。整枝後, 茶株面の冬芽 20 本にラベルを付け，以後翌 年 3 月 20 日まで経時的に芽長をセルロイド のスケールで測定した（調查日：10月 4， 12,20 日，11月 $1,9 ， 20,30$ 日，12月 11 , 20 日， 1 月 $9 ， 30$ 日， 2 月 $16 ， 22$ 日， 3 月 $5,13,20$ 日)。

芽長の測定上同日に冬芽を任意心 20 芽採 集し, 芽を解体して芽の中に存在する幼葉数 を実体顕微鏡下で数えた。

なお，以上の試験は，秋整枝によって切断
された枝条先端部に形成された側芽を用い， ラベル付けと採集は，茶株面の東肩と西肩か ら同数ずつ行った。また，幼葉数には包葉も 含めた。

\section{3 結果}

調查年に扣ける最高, 最低気温の推移を図 1 亿示した。調查年は，1月下旬の低温を除 き暖冬で，特に 2 月の気温は平年よりも非常 に高く推移した。

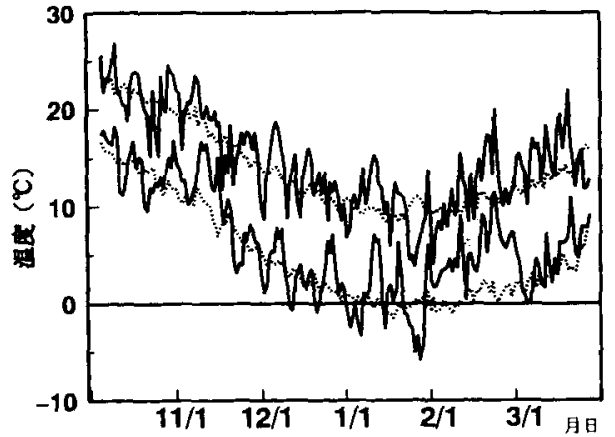

図 1 最高, 最低気温の推移 1989-1990 平年

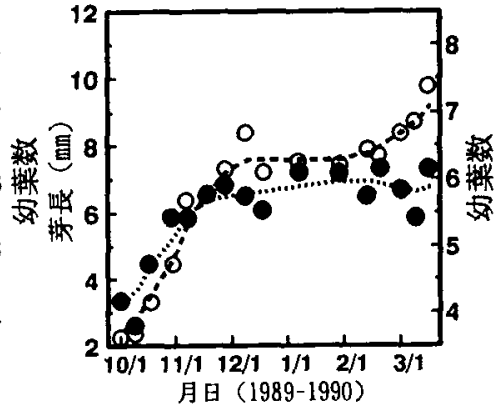

图4 ‘やまかい’の冬芽の生育

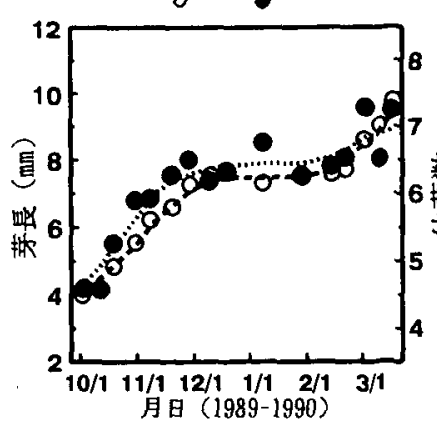

図5 'やぶきた' の冬芽の生育 芽長 奻葉数
図3 ‘さやまかおり”の冬芽の生育
芽长 幼菜数

図3 ‘さやまかおり’の冬芽の生育
芽長 幼菜数
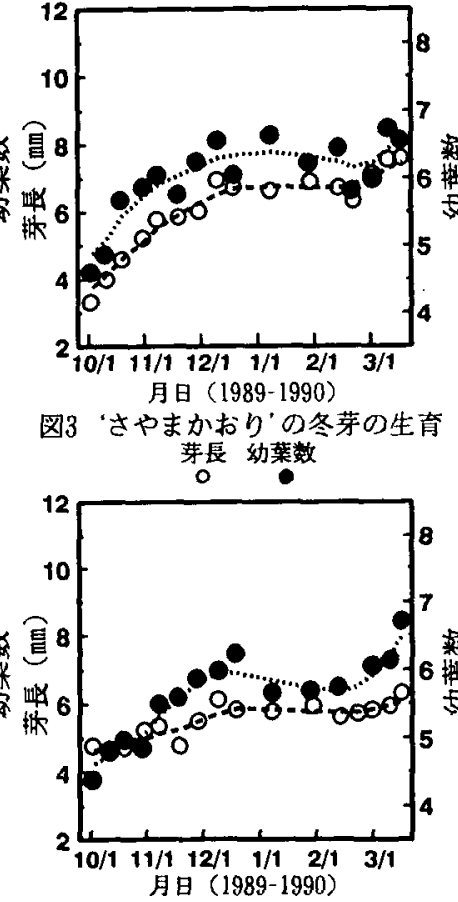

図6 ‘かなやどり’の冬芽の生青 芽長 幼葉数

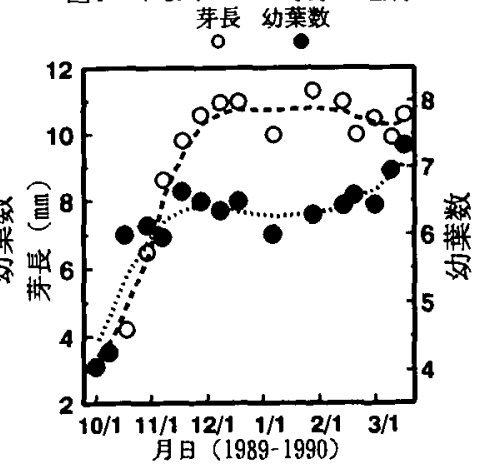

図7 ‘くひかり’の冬芽の生育 芽長 幼葉数 


\section{1 芽長の推移}

芽長は各品種とも秋整枝直後から増加し, 概ね12月上旬以降には增加が停止した。停止 する時期は，“おくひかり’が他の品種より 若干早い傾向であった。

“お拉いわせ，やまかい，やぶきた’の 3 品種は翌年 2 月下旬以後再び增加した。他の 3 品種は増加量が僅かであるかあるいはほ上 んど認められなかった。なお，この時期に和 ける増加量は，前年秋から冬をでの増加量よ りも少なかった（図 $2 \sim 7)$ 。

\section{2 幼葉数の推移}

各品種とも幼葉数は芽長之同様に秋整枝直 後から增加し, 冬季に停止した。‘やまかい, やぶさた，括くひかり’ の幼葉数増加停止期 は, 芽長の増加停止期よりも早い傾向にあっ た。

‘やぶきた，かなやみどり，拈くひかり’ の中一晚生品種の幼葉数は，翌年 3 月上中旬 から再び增加した。しかし，この時期に扣け る増加量は前年秋から冬をでの増加量に比較 すると少なかった。一方，“扮执いわせ，さ やまか括り，やまかい，の早〜中生品種は， 増加量が僅かであるかあるいは活とんど認め られなかった（図 $2 \sim 7$ )。

\section{3 一番茶新芽の生育}

芽長調査を行った冬芽について一番茶新芽 の生育状況を調查し，その結果を図 8〜9に 示した。な拉，“やまかい’については，灰 色かび病が発生し欠測值が多くなったので省 略した。

供試した品種の一般的な早晚性は，摘採期 の早い方から“打执いわせ，さやまか颃り， やぶきた，かなやみどり，扰くひかり’の順 である。しかし，供試は場に打ける“さやま かおり’の一番茶芽生育は，毎年“やぶきた” よりも遅い傾向で，これは栽植位㯰間におけ る微気象の差が影響していると考古られる。 また， ‘かやみどり' の樹勢は非常に悪か った。したがって，本試験に扣ける一番茶芽 の生育は，“打扔いわせ，やぶきた，打くひ かり，さや去かおり，かなやみどり’の順で 早く, 品種の一般的な早晚性と大きく異なった。

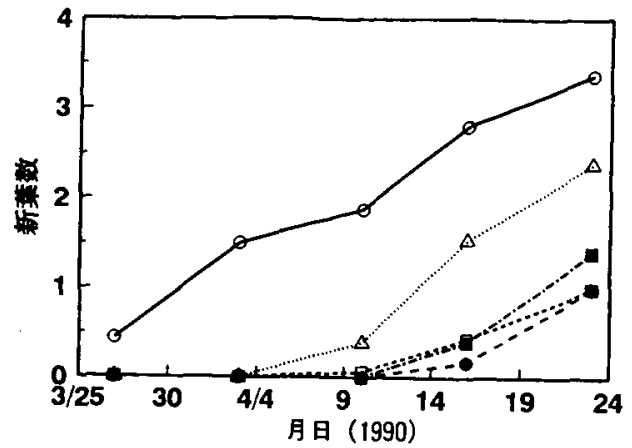

図 8 一番茶芽に批名新葉数の推移

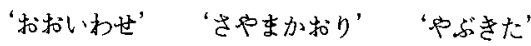

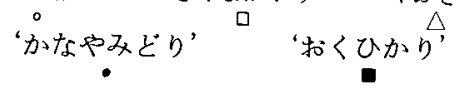

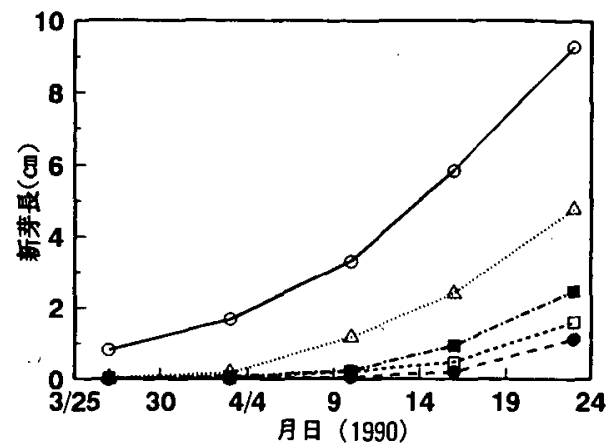

因 9 一番茶芽に打ける新芽長の推䔟

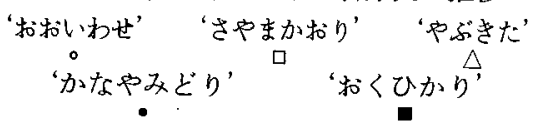

\section{4 考察}

供試した全ての品種に执いて，秋整枝直後 から芽長と幼葉数が増加したが，12月上旬 になると幼苯数の増加は停止し，それと同時 若しくはその後まもなく芽長の増加も停止し た。これらの停止期は翌年 2 月中旬まで続い た（図 2〜7）。これまでに中山ら”方が ‘ ぶきた，やまとみどり'等の品種を用いて， 2 月 10 日から萌芽期直前までの芽長や幼葉 数の推移を検討しているが，それ以前の時期 については明らかでなかった。

八戸ら1), 策瀬了》は，冬季のチャ枝条を生 育好適条件下に放置しても頂・側芽が伸長し ない現象をチャの自発休眠とし，同条件下に 
おけ萠芽までの所要日数から自発休眠の推 移を検討している。策瀨 3 ) は静岡県金谷で行 った研究から，品種によって多少の違いはあ るが12月下旬から1月上旬にか沙て萌芽所要 日数が最も長くなったと報告している。筆者 らが観察した芽長, 幼葉数の増加停止期もこ の期間を含んでいることから，これはチャの 休眠期を示寸現象であると考克られる。

“扮批いか世，やぶさた，や加”の 3 品種は 2 月下旬以後再び芽長の増加が始まっ た（図2，4，5）。“や加”については不 明であるが，“打拉いわ，やぶきた’の一 番茶新芽の生育が早かったこと（図 $8 ， 9$ ), また萌芽という現象が質的な变化でなく，む しろ芽の生育に伴ら量的な变化であることか ら，ここでみられた芽長の増加は一般的な品 種の早晚性ではなく，本試験に沶ける生育の 早晚に結びつくものと考克られた。

‘やぶきた，かなやみどり，和くひかり’ の中～晚生品種は 3 月上中旬から再び幼葉数 が増加した（図 5，6，7）。この現象と本試 験に猢る一番茶新芽の生育の早晚（図 8 ,

9) との関連性が見いた゚せないことから，こ の時期の幼葉数増加の有無は品種固有の特 性, 即占品種の早晚性に関連性が高い形質と 考えられる。中山ら2) むやや゙きた'と‘や まとみどり’で，2月10日に打るる幼葉数 と6月 8 日に拈ける出開き状態の新芽の開葉 数との差を比較し, ‘やぶきた’よりも晚生 の ‘やまとみどり’で増加数が多かったこと を報告している。幼葉数の増加は展開葉数の 增加を促すが，これは一番茶新芽の生育期間 を引き延ばす効果もあると考えられる。

今回の調查の結果, 冬芽の芽長や幼葉数は 秋整枝直後から 12 月上旬までの期間と 2 月 下旬以降の 2 回に分けて増加することが明ら かになった。前者の增加量は概权後者よりも 多いが、明らかな品種間差はみられなかった。
一方, 2 月下旬以降に和ける増加パターンに は品種間差が認められた。冬芽のこのような 生青特性は, 萌芽期前の茶芽の生育状況を知 る指標になるばかりではなく，一番茶の收量 の成立過程を解明する手がかりにもなると考 えられる。しかし, 年次間差や肥培管理の違 いによる影響，また一番茶の生育収量との関 連性など不明な点は多く残されている。した がって, 今後これらの点を詳細化解明する必 要があらら。

\section{5 摘要}

秋整枝から翌春一番茶萌芽期前にかけて

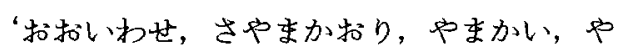
ぶきた，かなやみどり，扰くひかり’に特け る冬芽の芽長と幼葉数の推移を調查した。

全ての品種に打いて，芽長と幼葉数は秋整 枝直後から増加したが，12月上旬頃には停 止した。幼葉数の増加停止期は, 芽長の停止 期よりも早い傾向であった。

翌年 2 月下旬以降の增加については, 品種 間差が認められた。即ち，芽長が増加したの は，“扮打いわせ，やまかい，やぶきた’で， 幼葉数が增加したのは， ‘や゙きた，かなや みどり，持くひかり’の中〜晚生品種であっ た。また，この時期の芽長や幼葉数の増加量 は, 前年秋整枝直後から 12 月上旬までの増 加量よりも少なかった。

\section{6 引用 文 献}

1）八戸三千男 · 近藤貞昭 - 池田奈実子 · 和 田光正・根角厚司（1988）：暖地に打け るチャ品種の休眠特性と気象要因の影 響, 野菜·茶試研報 D-1,69-78.

2）中山仰・原田重雄（1960）：茶芽の発育 に関する形態的研究, 茶研報, $23,1-5$.

3）策瀬好充 (1971) : 茶樹の冬芽の休眠に 関する研究，日作紀，40（別2），33-34. 